\title{
Nume de familie din Feleacu (Jud. Cluj)
}

\author{
Rozalia Colciar \\ Academia Română, Institutul de Lingvistică \\ și Istorie Literară „Sextil Pușcariu”, Cluj-Napoca, România
}

Family names in Feleacu village (Cluj county)

\begin{abstract}
This study is dedicated to family names in Feleacu, an old Romanian village near the city of Cluj-Napoca.

The family name, a part of the category of official anthroponyms, is a group name usually having a hereditary father-to-son transmission. From this point of view, there are old names like Nicoară, Şimon, Bojan, Balea etc. (more families, probably related once, bear the same name). There are also names belonging to only one family that is usually recently established in the village: Bogdan, Andreica, Gligor etc. The study approaches the etymology of these names as well.

In addition to official names, there exists a parallel system of unofficial names, consisting of nicknames and surnames that we approached in another study.

In many situations the unofficial name substitutes the official one, helping in identifying a family, especially when more families bear the same name.

Keywords: official anthroponyms, family names, unofficial anthroponyms, nicknames, surnames.
\end{abstract}

1. În cadrul procesului de comunicare, indivizii pot fi identificați prin două tipuri de unități/sintagme/formule antroponimice distincte, dar în același timp echivalente: formule convenționale (oficiale) și formule neconvenționale (neoficiale) ${ }^{1}$. Dacă antroponimele neconvenționale se supun unor reguli neoficiale, fiind produsul vorbirii individuale, antroponimele convenționale sunt produsul unor reguli standardizate de canoanele normative oficiale.

Numele de familie face parte dintr-o formulă antroponimică oficială (convențională $)^{2}$, alături de numele individual. Dacă acesta din urmă este autoreferențial și are un referent unic (persoana numită) reprezentat de prenume, numele de familie are referent multiplu și trimite la grupul familial căruia îi aparţine individul. În cadrul

1 Ca unitate comunicativă, actul verbal de numire este un act declarativ: printr-o secvență lingvistică (componentă locuționară), locutorul transpune în limbaj, prin intermediul unui verb performativ (componentă ilocuţionară), o realitate extralingvistică, influențând sistemul de cunoștințe al interlocutorului (componentă perlocuționară), cf. Felecan 2014: 56-57; 95-97.

2 Ionescu Perez (2016: 66) definește formula antroponimică oficială drept „résultat d'une codification juridique étatique de tous les aspects de l'usage des anthroponymes dans le processus d'identification des individus, appliquée par l'institution de l'état civil". 
acestei formule binominale, prenumele este un nume ales, pe când numele de familie este transmis ereditar, patriliniar/matriliniar sau schimbat pe cale oficială.

Ca nume convențional (oficial), numele de familie implică un fenomen de individualizare istorică, el fiind recunoscut la nivelul întregii comunități. Deși monovalent (denumește o clasă, un grup), el este plurivoc, caracterizat printr-o multiplicitate denotativă (vizează mai mulți semnificați, trimite la mai mulți referenți, membri ai aceleiași clase). Individualizarea propriu-zisă în cadrul formulei antroponimice o realizează numele individual (prenumele).

2. Lucrarea noastră își propune să urmărească unele nume de familie mai vechi din satul Feleacu (jud. Cluj). Materialul care stă la baza acestui studiu a fost extras în principal din registrele agricole ale anilor 1956-1958, 2015-2017, precum și din lista cu numerele de casă aflată în arhiva Primăriei în anul 2017. De asemenea, ca surse complementare, am avut în vedere și numele de familie notate de cercetătorul științific Sabin Vlad cu ocazia anchetei toponimice efectuate în Feleac, în anul 1984, precum și propriile informații, ca localnică și vorbitoare de grai.

Precizăm că am urmărit doar numele de familie mai vechi, aparținând familiilor stabilite aici până în secolul al XX-lea, deoarece la ora actuală, din totalul celor aproximativ 1030 de familii, aproape jumătate sunt reprezentate de nou-veniţi în sat, în condițiile unei migrații masive de la oraș la satul situat la doar $7 \mathrm{~km}$ de municipiul Cluj-Napoca.

Feleacul este un sat vechi românesc, menționat pentru prima oară în documentele istorice la $1366^{3}$. La 1367, din porunca regelui Ludovic I de Anjou, satul este mutat de pe vârful dealului mai jos, pe versantul nordic și alipit Clujului, sătenii având sarcina de a păzi vechiul drum roman dintre Cluj și Turda ${ }^{4}$. Odată cu scăderea importanței acestui drum roman și medieval și, implicit, a rolului felecanilor de paznici ai Drumului Clujului, satul revine treptat pe deal, în vechea vatră, care de altfel nu fusese părăsită complet niciodată. Astfel, identitatea felecanilor se structurează pe două coordonate: statutul lor de țărani liberi - paznici ai drumului, supuși orașului regal Cluj și existența unui important centru eclesiastic și monahal ortodox pe deal, organizat în jurul bisericii Sf. Paraschiva, construită la 1488 și ctitorită de Ștefan cel Mare, centru monahal unde, la sfârșitul secolului al XV-lea și începutul secolului al XVI-lea, și-a avut sediul Mitropolia Severinului 5 .

În studiul istoricului Alexandru Simon, Feleacul (1367-1587) (2004: 170 ș.u.) se amintește faptul că, încă la 1446, într-un document al Conventului din Cluj-Mănăștur, apare pomenit un Ștefan Feher (Albu) din Feleac, aflat într-un conflict cu un iobag de pe domeniul Tăuți. În secolul al XVI-lea (1534-1598), în actele clujene erau consemnate

3 În toponimul Felek Berch (Dealul, Vârful Feleacului) și în hidronimul Felek pataka (Valea Feleacului), cu ocazia hotărnicirii din 1 iulie 1366 a pământurilor Clujului (cf. DRH, 1994, nr. 97, p. 167-170). Cf. și Suciu I, 1967: 229.

${ }_{4}$ Cf. I.-A. Pop et alii, De vertice montis. Feleacul, Clujul și Transilvania în Evul Mediu (2017: 37 ș.u.).

5 Cf. Al. Simon, Feleacul (1367-1587) (2004: 97-134). 
patruzeci și unu de nume (de familie, probabil) existente în Feleac: Balea (Bulia -?), Bota, Botoș, Copos (Kopoz), David, Dicea (Decre -?), Fagoș (Fogász), Filip, Giurcă (Gyurka), Goșa, Horga, Husar, Iepure (Nywlas), Itu, Katona, Kerekes, Korchioliass, Macaria, Mezaroș, Micu (Kis), Nicoară, Pascu, Pop, Roman, Roșca, Șimon (Simon), Stănilă (Saniszló -?), Șerb (Serui -?), Șipoș, Tașca (Taska), Torșa, Trefa, Vaida (Wayda) - cnezul de Feleac, Varga, Vlad (László-?), Zebresi, Zogorean (Zwgoryan). Dintre acestea, sunt întâlnite astăzi ca nume de familie, Balea, Nicoară, Pop, Șimon și Şipoș, Horga (în toponimul Dealul Horghii), iar ca supranume sau porecle, Cătana, Crăciun, Filip, Nulaş, Paşcu, Román și Varga.

În secolul al XVII-lea, mai apar în documente nume precum Lupu (Farkas), Ruşca (Ruszka) și Rusu (Orosz), dintre care se păstrează astăzi Rusu și Ruşca, ultimul, în toponimul Tăul Rușchii. Cu certitudine existau și alte nume de familie, dar care nu au fost păstrate în documente, acestea din urmă reținând adesea doar prenumele persoanei, precum Costea, Dionisie, Matei sau Radu și, uneori, locul său de proveniență. Alexandru Simon, op. cit. explică originea acestor nume din documentele istorice prin raportarea lor la porecle, supranume sau prenume și emite ipoteza, foarte plauzibilă, că unele nume trebuie să fi circulat sub altă formă în comunitatea satului, actele înregistrând o formă maghiarizată a numelor. De asemenea, o raportare la criterii etnice sau regionale în explicarea acestor nume este imposibilă, satul fiind compact românesc. Se poate doar presupune că, în secolul al XIV-lea, odată cu mutarea satului, precum şi în secolul al XVIII-lea, prin revenirea lui pe deal, au venit români din alte regiuni ${ }^{6}$. Doar migrări sau roiri masive de populație, eminamente de coloratură etnică românească și care au dus la absorbirea vechilor familii, pot explica o creștere cu 80\% a numărului de familii felecane în secolul al XVIII-lea, în perioada în care satul revenea din Pustă pe deal. Altfel spus, în decursul a două secole și jumătate, 80\% din numele vechilor familii felecane s-au stins $s^{7}$. Nou-veniții se asociază nucleului felecan tradițional, asumându-și moștenirea lăsată de vechile familii, mărcile identitare ale satului conturându-se în jurul proprietății asupra terenurilor și al poziției în interiorul comunităţii.

În registrele parohiale din prima jumătate a secolului al XIX-lea mai apar doar cinci din vechile nume de familie: Balea, Nicoară, Pop, Roșca (probabil vechiul Rușca) și Șimon, cărora li se adaugă și numele Pădurean.

3. Prin compararea datelor din registrele agricole ale anilor 1956-1958 și 20152017, se poate constata faptul că numele de familie din Feleacu au rămas aceleași, cu foarte mici diferențe:

6 David Prodan (1968: 690-692) amintește despre noii și vechii felecani, distincție apărută la 1592, an în care vechii felecani se adresează orașului cerând să pună capăt stabilirii de venetici pe pământurile lor. Este vorba deci despre admigrări recente (o generație) datorate condițiilor de viață prielnice pe care Feleacul le oferea.

7 Din preajma lui 1600, până după 1826 , de când datează cel mai vechi registru parohial din Feleac. Cf. Simon 2004: 172 și passim. 


\begin{tabular}{|l|c|c|}
\hline Numele & Anul 1956 & Anul 2015 \\
\hline BALEA & 56 familii & 58 familii \\
\hline TANȚĂU & 50 familii & 47 familii \\
\hline BOJAN & 44 familii & 41 familii \\
\hline NICOARĂ & 33 familii & 25 familii \\
\hline POP & 23 familii & 33 familii \\
\hline RUS(U) & 23 familii & 26 familii \\
\hline ȘIMON & 25 familii & 13 familii \\
\hline
\end{tabular}

Nume precum Butean, Doduț, Lobodă, Petrean sau Urcan, înregistrate în 1956, au dispărut astăzi, prin lipsa unor purtători ai numelui sau prin plecarea familiilor în altă parte. De asemenea, nume precum Căpâlnaș, Chintovan, Faur, Fălcuşan, Hiriț, Ielcean, Mercean, Pedea, Perșa sau Tat, unele neconsemnate la 1956, erau percepute de localnici ca nume noi, informatorii precizând, în ancheta toponimică efectuată de Sabin Vlad în anul 1984, că purtătorii lor sunt veniți din altă parte, uneori chiar menționând numele localității de origine a acestora.

Materialul cules poate fi clasificat astfel:

\subsection{Nume de familie provenite din antroponime:}

3.1.1. formate pe teren românesc:

- Costea < prenumele Coste este considerat în DOR: 34 ca un hipocoristic al lui Constantin + suf. antrop. -a. Iordan DNFR: 150 trimite la gr. Kostea(s) și la bulg. Koste (cf. și Loșonți 2015);

- Dumitru < pren. Dumitru;

- Gheorghiță < hipocoristicul Gheorghiță < pren. Gheorghe + suf. dim. -iță;

- Gliga < pren. Gliga, hipocoristic al lui Gligor, variantă a lui Grigore; cf. și bulg. Gligo, Gligor (DNFR: 226; Loșonți 2015);

- Gligan < pren. Gliga + suf. -an;

- Marc, Marcu < pren. Marcu, nume biblic (DNFR: 291; Loșonți 2015);

- Nicoară - prenume vechi, la baza căruia se află lat. Nicolas; cf. și DOR: 117;

- Trif < pren. Trif, hipocoristic al lui Trifon, nume de sfânt (Loșonți 2015). Iordan, în DNFR: 461, îl explică drept un derivat de la Trifan < Trifa, Trif(u) + suf. -an (< bulg. Trifa).

3.1.2. imprumutate din maghiară:

- Gherghel < pren. magh. Gergely „Gregor”;

- Micle < n. fam. magh. Mikle < pren. magh. Mikle, hipocoristic al lui Miklós „Nicolas” (Kázmér RMCsSz; Loșonți 2015);

- Miclea $<$ n. fam. Micle + suf. antrop. - $a$;

- Șimon < pren. magh. Simon „Simion”, nume biblic (DOR: 147; DNFR: 434; Loșonți 2015).

3.1.3. de origine slavă:

- Marian < sl.; cf. bulg., ucr., rus., pol. Marian (Loșonți 2015);

- Mihalca < bulg. Mihalka (DNFR: 305); 
- Neag $(u)$ < pren. Neagu < sl. Njago (DNFR: 327; Loșonți 2015);

- Nechifor, variantă a lui Nichifor < bulg. Nikifor; cf. ucr., rus. Nikifor (DNFR: $328,332)$;

- Nicula < sl.; cf. pren. bulg. Nikula (DNFR: 334);

- Rad(u) < pren. sl. Rad, Rado < adj. sl. radŭ „,bucuros, vesel”;

- Vanca < sl.; cf. pren. blg. Vanka < sl. Ivanka. Familia este cunoscută cu supranumele Oanca.

3.2. nume de familie provenite de la supranume care arată originea locală a purtătorului inițial:

- Abrudan < abrudan „persoană originară din Abrud”;

- Bojan < bojean „persoană originară din Boju CJ”;

- Cărean (sau Cărian) < cărean „persoană originară din Carei SM (Loșonți 2015) sau din Cara CJ";

- Crișan < crișean „persoană originară din regiunea traversată de râurile Criș”;

- Hațegan < hațegan „persoană originară din zona Hațegului”;

- Iudean < Aiudean < aiudean „persoană originară din Aiud AB”;

- Micuşan < micuşan „persoană originară din Micuș (azi Micești) CJ”;

- Moldovan < moldovean „persoană originară din Moldova”;

- Múncaci < n. fam. magh. Munkácsi „persoană originară din orașul Munkács, din Carpații Ucrainei” (cf. Kázmér RMCsSz; Loșonți 2015);

- Muntean < muntean „persoană originară din Muntenia sau dintr-o zonă muntoasă";

- Mureșan < mureșean „persoană originară din regiunea Mureșului”;

- Pădurean < pădurean „persoană originară din regiunea Pădurenilor sau de pe lângă vreo pădure";

- Runcan < runcan „persoană originară din Runc, Runcu (numele mai multor localități din țară, cea mai apropiată fiind în jud. Alba)";

- Sălăjan, cu var. magh. Selejan, < sălăjean „persoană originară din zona Sălajului”;

- Vădean < vădean „persoană originară din Vadu CJ”.

\section{tătorului iniţial:}

3.3. nume de familie provenite din supranume ce indică originea etnică a pur-

- Rus $(u)<\operatorname{rus}(u)$ „persoană de origine ruteană (cf. Loșonți 2015) ${ }^{8}$;

- Sechelea < n. fam. magh. Székely < székely, „secui, grup etno-lingvistic de limbă maghiară din Transilvania" + suf. antrop. - (e)a.

3.4. nume de familie provenite din supranume ce indică ocupația sau îndeletnicirea purtătorului inițial:

3.4.1. formate pe teren românesc:

- Pop < rom. pop, formă veche a lui popă „preot” (<v. slav popŭ);

- Popa < rom. popă;

8 Despre rușii sau rutenii colonizați în Transilvania și deznaționalizați, a se vedea Drăganu (1928: 74-83). 
- Poruț(iu) < n. fam. rom. Pora + suf. dim. -uț(iu); cf. și n. fam. magh. Pora < por „țăran”, bulg. Por(o) (DNFR: 375, 376).

3.4.2. împrumutate din maghiară:

- Suciu < n. fam. magh. Szücs < szücs „blănar, cojocar”;

- Șipoș < n. fam. magh. Sipos < sipos „cântăreț din fluier”.

\section{5. nume de familie provenite din supranume sau porecle care indică însușiri ale purtătorului inițial:}

3.5.1. formate pe tren românesc, prin derivare:

- Balea < n. fam. rom. Bale + suf. - $a$; cf. scr. Bale; 104);

- Călbăjos < adj. călbăjos < călbejos, var. a lui gălbejos „palid, tras la față” (DNFR:

- Cătinaș < adv. adj. cătinaș (sin. cu cătinel) „încetișor” (DNFR: 107);

- Cioplea < vb. a ciopli + suf. -ea. Iordan, în DNFR: 126, consideră că provine din subst. Cioplea „dracul sau un alt duh rău”. Prin literarizarea greșită a formei fonetice locale [śóplĖa], a fost consemnat în acte, în cazul unei familii, ca Șoplea.

- Florea $<$ n. fam. Flore + suf. - $a<$ pren. Floare $<$ s. c. floare.

3.5.2. imprumutate din maghiară:

- Corcea < n. fam. magh. Korcs < adj. magh. korcs „corcit, bastard, degenerat” (DM-R: s.v.) + suf. -ea. Supranumele familiei este Varga < n. fam. magh. Varga < s. com. varga „cizmar”.

- Harșa < n. fam. magh. Hárs < s. com. magh. hárs „tei” + suf. - a (DM-R: s.v.);

- Hoda < n. fam. magh. Hóda < s. com. hóda „pasăre acvatică” (DNFR: 243; DM-R: s.v.);

- Tanțău, cf. n. fam. magh. Tánczos < s. com. táncos „dansator, jucător” (DM-R: S.v.).

- 3.5.3. de origine slavă:

- Blag < sl. blag „bun”; cf. bulg. Blaga, sinonim cu Dobre „bun” (DNFR 66);

- Dușa < sl. Duša < subst. sl. duša „suflet” (DNFR: 187); cf. și n. fam. rom. Suflețel.

În Feleac, antroponimele oficiale (convenționale) sunt utilizate și astăzi în paralel cu antroponimele neoficiale (neconvenționale), reprezentate prin supranume sau porecle. Un singur nume de familie trimite la mai multe „neamuri” (familii), care e posibil să fi avut un strămoș comun. Un singur semnificant se caracterizează printr-o multiplicitate denotativă, trimițând la mai mulți referenți. Este vorba nu numai despre membrii aceleiași familii (neam), ci despre mai multe familii sau neamuri purtătoare ale aceluiași nume. De exemplu, numele de familie Nicoară trimite la neamurile cunoscute cu următoarele supranume sau porecle: a Bíţului, a Morocoáşii, a Penúţii, a lui Mítrea, a lui Mirón, a lui Scuturíci, a lui Piștól; pentru n. fam. Balea - a Coroánii, a lui Cocáliț, a Máriii Păráschii, a Colibánului, a lui Pițimón, a Béșii, a Savínii; Bojan - a Pétrii Diácului, a lui Ilí-a lui Glígor, a lui Pipút, a lui Monéș, a Húii, a Pónii, a Căprárului; Pop - a lui Piștól, a Grófului, a lui Tódoru Lúchii, a lui Vasili-a Pétrii, a lui Ștefănúț, a Bégului, a Zghémbeții; Șimon - a lui Hórgoș, a Mărínii, a lui Simiónu Lúchii, a Mútului, a lui Samoílă, a Bucuríi; Nechifor - a lui Coceán, a Părăscúții, a Páșcului, a Beșoáii, a Chívului etc. 


\section{Concluzii}

Numele de familie trimite la un grup familial (tată, mamă și copii), referent multiplu. Format, în mod curent, în cadrul sistemului de denominație populară, supranume sau poreclă, numele de familie a fost preluat și a trecut în sistemul de denominație oficială, devenind o simplă formulă de identificare a persoanei, a neamului, transmițânduse de la o generație la alta $^{9}$. În Feleac, există și astăzi nume de familie vechi, care au supraviețuit de-a lungul secolelor (Balea, Nicoară, Pop, Șimon), în cadrul unui arbore genealogic extrem de ramificat, pe care lipsa documentelor istorice între secolele al XVI-lea și al XVIII-lea nu ne permite să-l studiem.

Distincția între grupurile purtătoare ale aceleiași nume de familie se realizează și astăzi cu ajutorul supranumelor/poreclelor, formule antroponimice echivalente numelor de familie.

Considerăm că studierea numelor de familie se încadrează într-un domeniu interdisciplinar, care vizează atât date de ordin lingvistic, cât și de ordin istoric și, nu în ultimul rând, de ordin genetic, domeniu care rămâne mereu o provocare pentru cercetător.

\section{Abrevieri şi referințe bibliografice}

DM-R = Dicționar maghiar-român, vol. I-II. 2011. Bucureşti: Editura Academiei Române.

DNFR = Iordan, I. 1983. Dicționar al numelor de familie româneşti. Bucureşti: Editura Ştiințifică şi Enciclopedică.

DOR = Constantinescu, N.A. 1963. Dicționar onomastic românesc. Bucureşti: Editura Academiei. Drăganu, N. 1928. Toponimie şi istorie. Cluj: Institutul de Arte Grafice „Ardealul”.

DRH = Documenta Romaniae Historica. C. Transilvania, XIII. 1366-1370. 1994. Editori [János] I. Dani, K. Gündisch, V. Pervain, A. Răduţiu, A. Rusu, S. Andea, no. 97, p. 167-170. Bucureşti. Felecan, D. 2014. Pragmatica numelui şi a numirii neconvenționale: de la paradigme teoretice la practici discursive. Cluj-Napoca: Editura Mega şi Editura Argonaut.

Ionescu Perez, P.C. 2016. La dérive des noms de famille. SCOL IX (1-2): 66-75.

Kázmér RMCsSz = Kázmér Miklós. 1993. Régi magyar családnevek szótára XIV-XVII. század. Budapest: Magyar Nyelvtudományi Társaság.

Loşonți, D. 2015. Les noms de famille dans la commune Bonțida (département de Cluj). SCOL VIII (1-2): 68-92.

Paşca, Ş. 1936. Nume de persoane şi nume de animale în Țara Oltului. Bucureşti: Monitorul Oficial şi Imprimeriile Statului. Imprimeria Naţională (Academia Română. Studii şi cercetări, XXVI).

Pop, I.-A., D. Marcu Istrate, T. Sălăgean, A. Simon. 2017. De vertice montis Feleacul, Clujul şi Transilvania în Evul Mediu. Cluj-Napoca: Academia Română. Centrul de Studii Transilvane.

Prodan, D. 1968. Iobăgia în Transilvania în secolul al XVI-lea, II. Bucureşti.

Simon, A. 2004. Feleacul (1367-1587). Cluj-Napoca: Presa Universitară Clujeană.

Suciu, C. 1967. Dicționar istoric al localităților din Transilvania, I. Bucureşti.

9 După Ștefan Pașca, în Nume de persoane și nume de animale în Țara Oltului, București, 1936, p. 62, în Transilvania, obligativitatea numelui de familie datează abia de la sfârșitul sec. al XVIII-lea, în urma unei dispoziții date de împăratul Iosif al II-lea. 